\title{
FILSAFAT KRITIK ATAS SEJARAH
}

\section{Pdt. Ivan Th. J. Weismann, M.Hum.}

\begin{abstract}
Abstrak
Perbedaan penjelasan Kaum positivisme dan Kaum relativisme dalam menilai obyektivitas atau tidaknya suatu pewnelitian sejarah harus dipandang sebagai pernyataan yang benar dan saling melengkapi sepanjang mengkonstruksi pernyataan-pernyataan yang benar
\end{abstract}

Filsafat sejarah menurut William H. Dray harus dimulai dengan membedakan dua arti "sejarah". Pertama, penggunaannya yang sering menunjuk pada rangkaian peristiwa-peristiwa dan tindakantindakan manusia di masa lampau atau yang sering dikenal sebagai kronologi. Kedua, pengunaannya yang menunjuk pada kajian sejarah itu sendiri (Dray, 1964: 1). Kedua, pengertian ini dihubungkan dengan disiplin filsafat, maka filsafat sejarah terdiri dari filsafat spekulatif sejarah dan filsafat kritik sejarah. Filsafat spekulatif sejarah berusaha menemukan dalam rangkaian peristiwa dan tindakan manusia di masa lampau suatu pola, struktur, tema atau makna yang melampaui bidang sejarah, seperti “apa arti (makna, tujuan) sejarah?" atau "hukum-hukum pokok mana yang mengatur perkembangan dan perubahan dalam sejarah?" dengan begitu sejarawan dapat membuat ramalan-ramalan mengenai perkembangan masyarakat di hari depan (Gardiner, 1985: 123). Filsafat kritik sejarah berusaha menjelaskan pokok-pokok seperti tujuan-tujuan penyelidikan sejarah, cara-cara sejarawan menggambarkan dan mengklasifikasikan bahan mereka, cara mereka sampai pada menyokong penjelasan-penjelasan dan hipotesa-hipotesa, anggapan-anggapan dan prinsip-prinsip yang menggarisbawahi tata cara penyelidikan mereka dan hubungan antara sejarah dan bentuk-bentuk penyelidikan lain (Gardiner, 1985: 124).

Tulisan ini tidak membahas sejarah sebagai suatu sistem spekulatif, tetapi membahas filsafat kritik atas sejarah yang sering dikaitkan dengan pertanyaan apakah tuntutan sejarah adalah saintifik atau tidak saintifik, seperti pada fisika, biologi, psikologi atau seperti pada ilmu-ilmu terapan diantaranya ialah keahlian teknik mesin. Jika sejarah ialah kajian ilmiah atau saintifik, maka metode sejarah harus menjadi metode ilmiah, dan sejarah akan diklasifikasikan sebagai salah satu cabang ilmu sosial. Pengertian ini dianut oleh kaum "positivis" dan penentangnya ialah kaum "idealis". Akan tetapi sejarah akan disalahmengerti jika perhatian utamanya selalu dimulai dengan tuntutan kualifikasi sebagai sains atau tidak. Oleh karena itu dalam pembahasan mengenai filsafat kritik sejarah, pertama akan mempertanyakan jenis pengertian atau penjelasan ilmiah tentang 
sejarah menurut positivis dan idealis. Selanjutnya, penulisan ini akan mempertanyakan apakah kesimpulan-kesimpulan penjelasan sejarah itu dapat berupa jenis objektivitas yang saintis capai. Hal ini menurut positivis (objektivis) dan relativis. Akhirnya, pembahasan ini akan mempertanyakan mengenai kausalitas dalam sejarah, berdasarkan pemikiran positivisme dan idealisme.

\section{Sejarah dan Pengetahuan Ilmiah}

Kaum positif beranggapan bahwa sejarah merupakan suatu studi ilmiah yang memiliki sifat-sifat pengetahuan ilmiah sebagai berikut:

a. Penyelidikannya secara metodis dan berhubungan secara sistematis, hal ini diperlukan untuk mendapat pengertian yang mendalam dan penilaian terhadap kesaksian dan bukti menjadi lebih dapat dipercaya.

b. Terdiri dari sekelompok besar kebenaran-kebenaran umum, istilah-istilah umum, dan bukannya merupakan penilaian universal seperti perangai dan sifat-sifat dari seluruh jaman atau manusia, tetapi penilaian universal tentang sifat-sifat umum dari orang-orang yang hidup pada suatu waktu tertentu dan dalam suatu daerah tertentu pula.

c. Metode ilmiah dapat membuat kita melakukan ramalan-ramalan yang gemilang sehingga menguasai jalannya peristiwa-peristiwa di masa datang, walaupun ahli-ahli sejarah tidak mempunyai tugas meramalkan masa datang, tetapi tidak pula dianggap tolol untuk mempertahankan keyakinan bahwa kita mempelajari masa lampau karena kita beranggapan studi itu akan membuat terang masa sekarang. Selain itu jika waktu lampau sama sekali tidak ada hubungannya dengan waktu sekarang, apakah kita masih menaruh minat mempelajari sejarah?.

d. Sifatnya objektif, yaitu setiap orang yang menyelidiki sejarah tidak berprasangka atau pun melibatkan kesenangan-kesenagan pribadi atau keadaan-keadaan pribadinya ketika buktinya itu diperhadapkannya (Walsh, 1950: 38-43).

Pandangan kaum positivisme ini, mendapat tanggapan dari kaum idealisme. Menurut kaum idealis, sejarah, karena memberikan sejumlah besar pengetahuan yang berhubung-hubungan dan yang dicapai dengan cara yang metodis, adalah suatu sains; akan tetapi suatu sains jenis yang istimewa. Sejarah bukannya suatu ilmu pengetahuan yang abstrak tetapi ilmu pengetahuan yang konkret, dan berakhir tidak pada pengertian umum melainkan pada pengertian tentang masing-masing kebenaran.

Sebab tujuan akhir dari semua penilaian ialah untuk memberikan sifat kepada suatu realitas berdasarkan tiap-tiap detailnya masing-masing. Ilmu-ilmu pengetahuan abstrak (sains) 
jelas tidaklah berhasil mencapai tujuan ini, sebab sains tidak melukiskan fakta yang konkret tetapi membahasnya di dalam kemungkinan-kemungkinan (hipotesa-hipotesa) belaka. Sains tidak menerangkan apa yang sebenarnya menjadi persoalannya, melainkan apa yang mungkin terjadi apabila syarat-syarat tertentu tercapai (Walsh, 1950: 46-47).

Jika kaum positivisme lebih prihatin pada kebenaran-kebenaran umum, maka kaum idealisme lebih prihatin pada rangkaian peristiwa yang unik dan tidak berulang. Pemahaman atas sejarah bagi kaum idealisme tidak dapat dijelaskan dengan cara-cara generalisasi, tetapi dengan cara-cara yang lebih detail (Dray, 1964: 8-9). Jawaban dari kaum positivisme ialah bahwa bukankah pandangan kaum idealisme tersebut dapat pula disebut sebagai suatu kebenaran umum? Dalam hal ini terdapatlah kesepakatan antara positivisme dan idealisme tentang sejarah, yaitu sama-sama mengakui suatu kebenaran umum tentang adanya hubungan antara peristiwa-peristiwa. Namun, pertanyaan tetap timbul bahwa apakah yang menjadi kriteria dalam memahami "hubungan" antara peristiwa-peristiwa sejarah?

Kriteria untuk memahami hubungan antara peristiwa-peristiwa menurut kaum idealis terdiri dari dua dalil. Pertama, bahwa peristiwa-peristiwa sejarah dipahami melalui mempelajari alam-alam pikiran dan pengalaman-pengalaman manusia. Kedua, pengertian sejarah adalah bersifat unik dan langsung atau dekat (Walsh, 1950: 53-54). Ahli filsafat Jerman, Wilhelm Dilthey (1833-1911) membedakan dengan tajam antara Naturwissenschaften atau ilmu pengetahuan tentang alam seperti biologi, kimia , fisika dan ilmu-ilmu lainnya yang menggunakan metode ilmiah induksi dan eksperimen, dibedakan Dilthey dengan Geisteswissenschaften atau ilmu pengetahuan tentang batin manusia seperti sejarah, psikologi, filsafat, ilmu-ilmu sosial, seni, agama, dan kesusasteraan. Menurut Dilthey pemahaman atas Geisteswissenschaften atau ilmu pengetahuan tentang hidup tergantung pada pengalaman-pengalaman batin kita, yaitu pengalaman yang tidak dapat dijangkau oleh metode ilmiah (Sumaryono, 1999: 50-51). Bagi Dilthey, mengatakan bahwa sejarah adalah secara tepat berhubungan dengan pikiran-pikiran manusia adalah sama pula dengan mengatakan bahwa sejarah adalah berhubungan dengan pengalaman-pengalaman manusia (Walsh, 1950: 55). Menurut Dilthey, proses pengertian alam pikiran orang lain adalah bagian dari pada pengertian alam pikiran kita sebagai suatu proses penafsiran (hermeneutik), bukan suatu proses menarik kesimpulan (Walsh, 1950: 56).

Menurut kaum idealisme, sejarah dipahami sebagai perbuatan-perbuatan dan pengalaman dari mental-pikiran, dan kita dapat mengerti sampai sedetailnya yang konkret karena kita sendiri punya pikiran. Alam harus kita lihat dari luar, akan tetapi 
pikiran dan pengalaman dapat kita lihat dari dalam (Walsh, 1950: 47). Sejarah hanya bisa dimengerti dengan melihat dengan jelas pikiran yang ada di dalamnya, sebab sejarah merupakan manifestasi pikiran (Walsh, 1950: 54).

Keberatan atas teori dari kaum idealisme ini ialah, mengatakan bahwa semua sejarah adalah merupakan sejarah dari pikiran berarti menyarankan bahwa setidak-tidaknya manusia membuat sejarahnya sendiri, bebas dari pengaruh ketentuan kekuatan alam. Keberatan lain, ialah bahwa pandangan kaum idealisme itu dapat terbukti apabila semua perbuatan manusia adalah dipertimbangkan dengan masak-masak, sementara banyak diantaranya yang jelas tidak dipertimbangkan masak-masak, oleh karena pelaku sejarah dalam keadaan terpaksa, atau terdesak/mendadak. Keberatan yang lainnya lagi, ialah bahwa dengan pandangan kaum idealisme itu, berakibat mempersamakan apa yang ada di dalam pikiran orang lain dengan apa yang ada di balik pikirannya sendiri, padahal, pikiran menurut definisi adalah merupakan hal pribadi bagi orang yang memilikinya dan tidak ada seorang lain pun yang dapat sampai pada pikiran tersebut, salah pengertian akan timbul jika berusaha mencapai alam pikiran orang lain (Walsh, 1950: 58-62).

Pandangan kaum idealisme tersebut, Walsh memberikan kesimpulan bahwa tidaklah benar bahwa kita menyerap dan mengerti pikiran orang jaman dulu di dalam suatu kali perbuatan dari daya lihat yang intuitif. Kita harus menemukan apa yang sedang mereka pikirkan dan mendapatkan bukti yang berada di muka kita dan proses penginterpretasikan ini adalah suatu proses di mana kita setidaktidaknya membuat petunjuk secara implisit ke arah kebenaran umum. Ahli sejarah membutuhkan khayalan dalam tingkat besar, tetapi dia juga membutuhkan pengalaman (Walsh, 1950: 65).

Jalan keluar dari pertentangan antara kaum idealisme dan kaum positivisme tentang kriteria atau prosedur memahami peristiwa-peristiwa sejarah, ditawarkan oleh Walsh dalam penjelasannya tentang koligasi. Koligasi ialah prosedur menerangkan suatu peristiwa dengan jalan menyusuri hubungannya yang terkandung dengan peristiwa lain yang menempatkannya di dalam hubungan sejarah. Rangkaian peristiwa sejarah yang berhubungan membentuk suatu keseluruhan di mana tidak hanya perbuatan yang lebih akhir itu (kebenaran umum/tindakan pelaku sejarah) ditentukan oleh perbuatan-perbuatan yang mendahuluinya (peristiwa-peristiwa khusus/pemikiran pelaku sejarah), melainkan pula bersifat timbal balik, yaitu perbuatan yang lebih awal itu juga dipengaruhi oleh kenyataan di mana perbuatan yang lebih akhir sudah dapat dikenangkan dalam pikiran (Walsh, 1950: 67-68). Penjelasan atau pemahaman atas sejarah ialah menyusuri peristiwa-peristiwa khusus dan unik dengan menggunakan berbagai jenis metode termasuk salah satunya ialah metode ilmiah. 
Penjelasan dan pemahaman atas sejarah ini adalah sintesis dari segala pemikiran ke dalam sutu keseluruhan yang baru (Dray, 1964: 20).

\section{Objektivitas Sejarah}

Penyelidikan atas sejarah dipandang tidak dapat mencapai objektivitas dengan alasan adanya faktor-faktor subjektivitas, atau penilaian pribadi dalam diri sejarawan ketika melakukan penyelidikan sejarah. Menurut Nugroho Notosusanto (1984: 13-15), subjektivitas atau penilaian pribadi timbul karena:

a. Sikap berat sebelah pribadi (personal bias). Ada sejarawan yang menyukai pahlawan-pahlawan. Ada yang membenci orang-orang besar, karena dianggap "membikin rusak dunia".

b. Prasangka kelompok. Suatu kelompok bangsa mempunyai prasangka terhadap suatu kelompok bangsa lain.

c. Teori-teori interpretasi sejarah yang bertentangan. Karl Marx mengatakan faktor ekonomi yang menentukan dalam proses sejarah. Hegel mengatakan akal yang menentukan sejarah manusia. Ada juga yang mengatakan "Politik adalah panglima".

d. Konflik-konflik filsafat. Ada yang mengatakan Tuhan itu Maha kuasa, yang lain malah menyangkalinya. Sehingga Tuhan tidak ada sangkut paut dalam sejarah.

Kaum Positivisme menegaskan bahwa mereka dapat mencapai objektivitas dalam sejarah. Sedangkan mereka yang menyangkalnya dapatlah digolongkan sebagai kaum relativisme (Dray, 1964: 21). Kaum relativisme beranggapan bahwa apapun usaha pemurnian yang diupayakan oleh sejarawan, dia tetap sebagai manusia yang tidak dapat dilepaskan bahkan sulit untuk dilepaskan dari kepentingan, budaya, kesukaan pribadi, dan prasangka dalam mengamati peristiwa sejarah (Dray, 1964: 22). Sementara kaum positivisme tetap mempertahankan bahwa tugas sejarawan adalah mengungkapkan fakta di masa lalu dan menjelaskannya berdasarkan hukum-hukum empiris yang sudah cukup memadai untuk tugas tersebut, sehingga tidak ada lagi tempat bagi faktor-faktor nilai atau subjektivitas dalam diri sejarawan yang harus dilibatkan, sebab hal itu hanya menimbulkan banyak kesalahan (Dray, 1964: 23). Kaum relativisme memberikan argumentasinya dengan mengatakan bahwa tindakan sejarawan selalu mengandung nilai, dan bahwa sejarawan dalam proses seleksi untuk mengkonstruksi penjelasan sejarah dituntun oleh nilai pula (Dray, 1964: 23-24).

Dua argumentasi dari relativisme ini menurut hemat penulis perlu didiskusikan secara khusus untuk mendapatkan solusi dari persoalan objektivitas sejarah. Pertama- 
tama, perlu didiskusikan tentang argumentasi bahwa tindakan sejarawan yang tidak dapat lepas dari nilai. Kaum relativisme mengatakan bahwa sejarawan harus berusaha mengesampingkan "sensor", untuk melakukan itu tidak bisa dengan mengesampingkan atau meminimalkan derajat moral atau evaluasi psikologis yang terkandung dalam tujuan dan motivasinya (Dray, 1964: 24). Sejarawan selalu berbicara secara evaluatif/subjektif mengenai pemikirannya tentang sejarah, oleh karena istilah-istilah yang digunakan tidak selalu dapat dijelaskan menurut kamus, tetapi juga mengandung makna subjektif sejarawan tersebut. Seorang sejarawan tidak dapat menulis tentang segala sesuatu tanpa mengenal dan mempelajari objek tersebut yang disertai nilai dalam dirinya (Dray, 1964: 24-25).

Kaum positisme yang diwakili oleh Ernest Nagel mempertanyakan apakah dalam setiap penyelidikan historis harus selalu disertai penilaian moral dan estetika? Herbert Butterfield menanggapi kaum relativisme dengan mengatakan bahwa "kehidupan dalam setiap incinya adalah masalah moral", akan tetapi kewajiban sejarawan tidak seharusnya turut mengambil kesimpulan-kesimpulan moral dalam mengamati hubungan antar peristiwa sebab penilaian moral itu adalah asing atau tidak relevan dengan alam intelektual (Dray, 1964: 25).

Jawaban relativisme atas tanggapan positivisme tersebut lebih jelasnya lagi dalam diskusi berikut ini mengenai argumentasi yang kedua dari relativisme bahwa proses seleksi dalam penyelidikan sejarah selalu dituntun oleh nilai. Suatu pernyataan berbunyi bahwa, "setiap sejarah yang tertulis adalah suatu seleksi atau pengaturan dari fakta-fakta, suatu pilihan, keyakinan dan penafsiran berdasarkan nilai-nilai" (Dray, 1964: 27). Kenyataannya adalah benar bahwa tidak ada sejarawan dapat memasukkan dalam tulisannya semua yang ia tahu tentang objek penyelidikannya. Oleh sebab itu dia perlu menyeleksi apa yang ia pikir penting dan signifikan, untuk melakukan ini disertai standar nilai tertentu. Penyusunan cerita historis menghendaki adanya evaluasi berdasarkan nilai-nilai tertentu (Dray, 1964: 27). Pemikiran ini tentunya didukung oleh kaum relativisme. Kelompok yang mempertahankan objektivitas sejarah menanggapi pemikiran tersebut dengan mengatakan bahwa sejarah bukanlah disiplin ilmu yang unik. Selain sejarawan para ahli ilmu alam juga dalam mempelajari segala sesuatu harus menyeleksi beberapa aspek atau persoalan. Jika para ahli ilmu alam dapat menyeleksi secara objektif kenapa sejarawan tidak dapat berbuat hal yang sama? Tangapan dari kaum relativisme, ialah bahwa persoalan seleksi dari sejarawan berbeda dengan seleksi dari para ahli ilmu alam. Perbedaannya terdapat pada dua jenis proses seleksi yaitu dalam menyeleksi suatu persoalan untuk dikaji dan menyeleksi apa yang harus 
dijelaskan sebagai solusinya. Pendukung objektivitas memikirkan tentang seleksi sebagai jenis proses seleksi yang pertama lalu kemudian menuduh kelompok relativisme menjelaskan cerita sejarah yang non objektif, sementara kelompok relativisme memikirkan seleksi berdasarkan jenis yang kedua (Dray, 1964: 29).

Persoalan objektivitas sejarawan dalam proses seleksi rupanya terletak pada masalah penjelasan. Sama seperti ada perbedaan seleksi antara sejarawan dengan para ahli ilmu alam, maka terdapat pula dua jenis penjelasan dalam sejarah. Pertama, ialah penyelidikan eksplanatori yaitu sejarawan menelusuri asal mula kejadian lembaga-lembaga dan budaya kontemporer, dan yang kedua, ialah penyelidikan deskriptif yaitu sejarawan merekonstruksi peradaban-peradaban yang maju di masa lalu sebagai suatu totalitas. Kaum positivisme memandang bahwa mereka dapat menjelaskan sejarah secara nonevaluatif karena menggunakan teori eksplanatori yang memberikan kondisi yang cukup untuk melakukan seleksi yang objektif. Sementara, sejarawan yang menggunakan teori deskriptif dalam menjelaskan sejarah dipandang oleh kaum positivisme mengalami kesulitan untuk mengesampingkan kriteria evaluatif, karena timbul persoalan seleksi dalam pengkajian sejarah. Persoalan seleksi bukan saja dalam pemilihan apa saja yang harus mejadi bahan penyelidikannya tetapi juga dalam penjelasannya. Contohnya, dua sejarawan yang menulis sejarah reformasi, yang satu adalah seorang Protestan dan yang lainnya ialah Katolik, akan menghasilkan penjelasan yang berbeda. Kaum positivisme memandang bahwa perbedaan seleksi ini adalah bukti tidak objektifnya dalam menjelaskan sejarah melalui teori deskriptif. Kaum relativisme memandang bahwa perbedaan seleksi terhadap apa yang dikenal untuk kemudian dijelaskan, tidak perlu disimpulkan bahwa mereka kemudian menulis penjelasan yang salah, dan tidak perlu pula dikatakan mereka saling bertentangan. Sepanjang penjelasan mereka yang berbeda itu adalah mengkonstruksi pernyataan-pernyataan yang benar, maka itu berarti mereka saling melengkapi. Jawaban mereka yang berbeda harus pula dipandang sebagai kontribusi bagi pandangan sejarah. Oleh karena itu penjelasan deskriptif atas sejarah tidak harus disimpulkan tidak dapat objektif (Dray, 1964: 30-31).

Kaum positivisme yang masih tidak puas mengenai persoalan seleksi memberikan pendapat bahwa ketika sejarawan memberikan penjelasan mengenai suatu periode atau masyarakat di masa lalu, seleksi memang harus ditentukan, tetapi bukan berdasarkan apa yang dipandang penting bagi sejarawan, melainkan berdasarkan apa yang nampak penting bagi orang lain, dengan cara ini penjelasan sejarah menjadi objektif, karena nilai yang diberikan bukan berasal dari dalam diri sejarawan tetapi dari pelaku sejarah yang diselidikinya, dan itu adalah "fakta sejarah" yang objektif. Geoffrey Barraclough 
sebagai pembela relativisme mengatakan bahwa, kita seharusnya menilai masa lalu berdasarkan standar orang-orang di masa lalu bukan berdasarkan ukuran kita, kita memandang penting apa yang penting mengenai fase-fase dan insiden-insiden juga tidak hanya berdasarkan apa yang penting menurut kita. Namun, pada tahap refleksi, sejarawan harus berfokus bukan pada apa yang penting, tetapi pada apa yang kita pikir adalah (atau harus menjadi) penting (Dray, 1964: 37).

Demi penyatuan dua pemikiran ini antara positivisme dan relativisme, maka dapatlah dikatakan bahwa dalam penyelidikan sejarah menggunakan dua sudut pandang: yaitu memahami masa lalu sejauh mungkin menggunakan istilah-istilah yang dimaknai sesuai dengan konteks masa lalu, tetapi kemudian, ketika sejarawan merekonstruksi sejarah masa lalu itu harus menggunakan nilai masa sekarang. Hanya saja kemudian timbul persolan lagi khususnya dalam menggunakan standar di masa lalu, standar yang mana yang harus digunakan. Misalnya dalam penulisan sejarah invasi Roma atas Britania, sejarawan menggunakan standar Orang Roma atau standar orang Britania? Atau dalam penulisan sejarah Reformasi Protestan, menggunakan standar orang Katolik atau Protestan? Menurut Dray, standar masa lalu yang digunakan ialah standar siapa yang pada amsa lalu itu benar-benar dipersoalkan (Dray, 1964: 38-39).

\section{Kesimpulan tentang Objektivitas Sejarah}

Persoalan mengenai objektivitas sejarah dalam pembahasan ini ditafsirkan bahwa objektivitas sejarah ekuivalen dengan sejarah yang bebas nilai. Christopher Blake mengatakan bahwa pertanyaan "apakah sejarah objektif" adalah pertanyaan yang bodoh, sebab itu sama saja dengan bertanya "apakah cerita itu menarik?" Yang seharusnya ditanyakan ialah "apa yang membuat sebuah sejarah objektif?" atau "apa jenis objektivitas yang dapat diharapkan dari seorang sejarawan?" (Dray, 1964:39). Untuk menjawab pertanyaan tersebut lebih dulu perlu didefinisikan arti "objektif". Ada yang mengatakan bahwa objektif itu ialah "tidak bias", "tanpa tendensius", tetapi ada juga yang mengartikan "objektif tidak sama dengan benar", juga tidak hanya harus diartikan "tunduk pada kebenaran", walaupun hal itu bagian dari objektif, ada juga yang mengartikan "luput dari sensor", atau "luput dari kepentingan" seperti propaganda, atau diartikan "tanpa nilai". Max Fisch merangkum semua definisi itu dengan mengatakan: "sejarawan tidak dapat dipersalahkan karena memuji dan mempersalahkan, dan tidak dipuji karena tidak melakukan kedua hal tersebut. Tetapi sejarawan dipersalahkan jika penilaian pribadinya membutakan dirinya pada bukti yang bertentangan dengan penilaiannya, dan ia akan dipuji jika seleksi dan perlakukannya terhadap bukti tidak semata-mata hanya untuk mendukung penilaian 
pribadinya atas pengembangan pencarian pembuktian. Sejarawan seni adalah seorang kritikus atas seni, sejarawan sains adalah seorang kritikus atas sains, sejarawan lembaga-lembaga ekonomi, sosial dan politik adalah kritikus atas lembaga-lembaga tersebut. Objektivitas bukan luput dari kritisisme, tetapi dengan nyata tunduk pada kritisisme yang lebih mendalam, terbuka sepenuhnya, dan bukan tidak dapat memberikan penilaian pribadi" (Dray, 1964: 49). Penggunaan kebebasan penilaian pribadi sebagai kriteria objektivitas dalam penyelidikan sejarah dapat saja menimbulkan asumsi bahwa penjelasan sejarah sudah tidak lagi menggunakan cara yang rasional. Demi mempersingkat diskusi persoalan ini, William H. Dray kemudian menyimpulkan tuntutan golongan positivisme bahwa logika adalah kriteria objektif dalam penyelidikan sejarah, harus pula diperlakukan sama kepada golongan relativisme yang menerima penilaian pribadi sebagai kriteria objektif dalam penyelidikan sejarah, dengan ketentuan bahwa penilaian pribadi tersebut dalam kerangka yang masuk akal, atau berdasarkan akal sehat (Dray, 1964: 40).

\section{Kausalitas dalam Sejarah}

Pembahasan kausalitas ini penulis sadur dari karya William H. Dray yang berjudul Philosophy of History, halaman 41-58. Persoalan kausalitas dalam sejarah yang didiskusikan dalam pembahasan ini berdasarkan pemikiran positivisme dan idealisme. M. R. Cohen dari positivisme mengatakan bahwa kausalitas merupakan sejumlah kondisi yang memadai dan seharusnya (yang memaksa) untuk terjadinya suatu peristiwa. Positivisme menambahkan pula bahwa kausalitas merujuk pada adanya hubungan yang jelas dan seharusnya antara kausa (sebab) dan efek (akibat). R. G. Collingwood sebagai pendukung filsafat idealisme tidak menyangkal kausalitas dalam sejarah, hanya saja menurutnya kausa harus digunakan dalam pegertian khusus. Menurut Collingwood kausa dalam sejarah bukan peristiwaperistiwa alamiah seperti yang dimaksud oleh positivisme, tetapi tindakan sadar dan bertanggung jawab dari pelaku sejarah. Kausa dari tindakan seseorang adalah motifnya untuk melakukan tindakan tersebut. Motif itulah yang "membuat", "menyakinkan", "menyebabkan", atau "mendorong", dan "memaksa" untuk berbuat. Collingwood menambahkan pula bahwa motif kausa tersebut harus memberikan kebebasan untuk berkehendak (bertindak) untuk menyangkal pengertian kausa menurut positivisme bahwa tindakan disebabkan oleh "kondisi yang memadai atau seharusnya" dari peristiwaperistiwa sebelumnya. Akan tetapi pada saat yang sama patut pula dipertanyakan definisi Collingwood tentang kausa, bahwa kausa itu adalah motif, dan motif itu, kata Collingwood yang "membuat" dan "memaksa" pelaku sejarah untuk bertindak. 
Tanggapan Collingwood atas kritikan itu ialah, kausa adalah motif atau pemikiran atau alasanalasan yang dipikirkan secara rasional oleh pelaku sejarah untuk bertindak. Selanjutnya, Collingwood berkata lagi, bahwa suatu kausa yang disebut sebagai suatu keharusan dari suatu tindakan dalam sejarah, bukan dalam arti bahwa tanpa kondisi yang merupakan keharusan itu, maka tindakan tidak dapat dilaksanakan, seperti yang dipikirkan oleh positivisme bahwa harus ada hubungan yang jelas dan seharusnya antara kausa dan efek. Jika demikian, menurut Collingwood berarti menyangkal "kehendak bebas" pelaku sejarah. Kondisi yang merupakan keharusan menurut Collingwood seharusnya hanya dalam arti bahwa tanpa kondisi tersebut maka tidak ada alasan yang memadai atau yang rasional untuk melaksanakan suatu tindakan. Kausa harus dipikirkan sebagai yang "memaksa" orang untuk bertindak, hanya dalam pengertian sebagai alasan yang memadai atau rasional untuk melakukan suatu tindakan, itu sebabnya kausa tersebut dikatakan "membuat", "memaksa", "mendorong" untuk melakukan suatu tindakan. Kausa dalam pengertian ini memang membatasi kebebasan individu, yaitu hanya dapat memilih beberapa pemikiran alternatif yang rasional saja. Tetapi kausa itu tidak menyangkal atau menghapus "kehendak bebas" pelaku sejarah, seperti dalam pemikiran positivisme yang mengatakan bahwa ada hubungan yang seharusnya antara peristiwa sebelumnya dengan tindakan berikut dari pelaku sejarah, sehingga tidak ada pilihan lain bagi pelaku sejarah, hal ini berarti menghilangkan kehendak bebas pelaku sejarah.

William H. Dray mengatakan bahwa pandangan Collingwood tentang kausalitas rupanya berbeda dengan teori positivisme tentang kausalitas. Positivisme memandang kausalitas berdasarkan pengamatan ilmiah yaitu merujuk pada peristiwa-peristiwa alamiah yang terjadi sebelumnya, sedangkan Collingwood memandang kausalitas sebagai ide atau pemikiran. Penulis tidak akan mendiskusikan lebih jauh mengenai manakah dianatara dua prinsip ini yang tepat disebut sebagai kausalitas, demi mempersingkat pembahsan ini maka penulis langsung saja membahas apa yang dikemukan oleh William H. Dray bahwa ada tiga teori kausalitas yaitu teori konspirasi, teori konflik, dan teori revisionis. Pemahaman atas tiga teori kausalitas tersebut diharapkan dapat memberikan pemahaman yang lebih jelas tentang prinsip kausalitas yang lebih tepat.

\section{Teori Konspirasi}

Teori konspirasi mengemukakan bahwa sebagai kausa ialah tindakan-tindakan dari individuindividu atau kelompok (para konspirator). Ketika bertanya siapa para konspirator, maka penilaian 
subjektif dari para sejarawan masih banyak dilibatkan, oleh karena para sejarawan kadang-kadang menjelaskan kausalitas sejarah dengan berpihak pada suatu kelompok tertentu, atau untuk propaganda, atau untuk mencari sensasi. Agar penilaian subjektif tersebut dapat diminimalkan, maka motif-motif dari semua pelaku sejarah dari masing-masing pihak yang bertikai perlu dianalisa dengan menggunakan konsep kausalitas, lalu sejarawan penganut teori konspirasi mengevaluasi tindakan-tindakan kelompok mana yang dapat digolongkan sebagai kausa atas suatu peristiwa perang misalnya.

\section{Teori Konflik}

Teori konflik menurut Howard K. Beale mengatakan bahwa kausa suatu peperangan misalnya, bukanlah suatu konspirasi kelompok tertentu tetapi suatu pertikaian antara dua kelompok dengan masing-masing kepentingan yang tidak dapat diperdamaikan. Kausa dalam hal ini bukanlah terdapat dalam respon dari berbagai para pelaku sejarah, tetapi kausa itu terdapat dalam situasi pertikaian itu sendiri, atau kondisi yang mengandung persoalan yang sulit. J. F. Rhodes mengatakan bahwa kausa bukanlah apa yang seseorang lakukan (respon) tentang perbudakan (misalnya), melainkan kausa adalah fakta yang ada dalam persoalan perbudakan tersebut. Keadaan sulit (pertikaian) itulah menurut teori konflik yang menjadi kausa, bukan tindakan dari para pelaku sejarah. Apa pun usaha yang dilakukan aktor sejarah tidak dapat melampaui persoalan sulit (pertikaian) sebagai kausa suatu peristiwa. Situasi persoalan yang sulit adalah kondisi yang memadai dan yang seharusnya sebagai kausa suatu peristiwa.

\section{Teori Revisionis}

Sebagai reaksi dari teori konflik, para revisionis menuntut para sejarawan untuk menegaskan kembali tanggung jawab manusia atas apa yang terjadi, dan para sejarawan juga harus membuat jelas bahwa peristiwa perang adalah suatu hal yang tidak perlu harus terjadi. Teori konflik, menurut revisionisme hanya mengesampingkan rasa bersalah dari kedua pihak yang bertikai. Menurut revisionisme, teori konflik berimplikasi bahwa perang, walaupun mungkin tidak dapat dihindari, tetap adalah sesuatu yang manusia pikirkan memang tidak dapat dihindari. Kebencian revisionisme atas perang membuat mereka mempersalahkan para aktor yang bertindak secara sadar tidak mampu mencegah timbulnya perang. Perang adalah hal yang tidak perlu dan dapat dikesampingkan, untuk itu perlu dicari tahu apa yang menjadi kausa dari tindakan para aktor sehingga gagal mencegahnya. 
Revisionime percaya bahwa manusia adalah mahluk yang berakal budi, sehingga dalam situasi konflik, perang dapat dihindari. Menurut revisionisme, hanya dalam kegilaan emosional dari mayoritas manusia yang membuat timbulnya perang dan perbudakan. Kritik atas revisionisme ini dapat dikatakan bahwa revisionisme gagal menafsir motif, dan perhitungan rasional dari mereka yang bertikai; sebab umumnya para pelaku sejarah bertindak berdasarkan pertimbangan moral dari pada berdasarkan perhitungan politik atau dorongan emosional. Apakah revisionisme atau pengkritiknya yang dapat diterima sebagai yang memberikan penjelasan yang memuaskan tentang kausalitas, bukanlah yang dipersoalakan dalam pembahasan ini. Pembahasan ini berusaha melihat apa yang dipersoalkan keduanya sebagai kausalitas. Kausalitas bagi revisionisme dan pengkritiknya sama-sama mengakui adalah persoalan moral lebih dari pada mengejar dominasi politik dan ekonomi atau mempertahankan suatu lembaga yang menggeramkan seperti perbudakan.

Kesimpulan tentang kausalitas dalam sejarah berdasarkan ketiga teori kausalitas tersebut yaitu konspirasi, konflik dan revisionis dapatlah dikatakan sebagai berikut: Kausa ialah motif atau pemikiran rasional dari para pelaku sejarah yang dipikirkan secara sadar, sengaja, penuh keterlibatan aktif, bukan karena terpaksa atau terperdaya. Selain itu, pemikiran rasional itu harus didasarkan pada pertimbangan moral.

\section{DAFTAR PUSTAKA}

Dray, William H., Philosophy of History, Prentice Hall, Inc, Englewood Cliffs, 1964.

Gardiner, Patrick, Filsafat Sejarah, dalam Ilmu Sejarah dan Historiografi Arah dan Perspektif, diredaksi oleh Taufik Abdullah dan Abdurrahman Surjomihardjo, Jakarta: PT Gramedia, 1985.

Notosusanto, Nugroho, Masalah Penelitian Sejarah Kontemporer (Suatu Pengalaman), Jakarta: Intidayu Press, 1984.

Sumaryono, E., Hermeneutik: Sebuah Metode Filsafat, Yogyakarta: Kanisius, 1999.

Walsh, W. H., Pengantar ke Arah Filsafat Sejarah (terj. Amir Harahap dan Pardjoko), Jakarta: U.I. Press, 1950. 